
The Rights and Wrongs of Abortion 



\section{The Rights and Wrongs of Abortion}

A Philosophy \& Public Affairs Reader

Edited by Marshall Cohen, Thomas Nagel, and THOMAS ScanLON

Contributors

JOHN FINNIS

JUDITH JARVIS THOMSON

MICHAEL TOOLEY

ROGER WERTHEIMER 
Copyright $\mathcal{C}$ I 974 by

Princeton University Press

Published by Princeton University Press, Princeton, New Jersey

and in the United Kingdom by Princeton University Press,

Chichester, West Sussex

All Rights Reserved

L.C. Card: $73-8268$

ISBN o-691-0I979-7 (paperback edn.)

ISBN 0-69I-07 197-7 (hardcover edn.)

$\begin{array}{llll}15 & 14 & 13 & 12\end{array}$

The essays in this book originally appeared in the quarterly journal Philosophy \& Public Affairs, published by Princeton University Press.

Judith Jarvis Thomson, “A Defense of Abortion," PGPA I, no. I (Fall 1971); Roger Wertheimer, "Understanding the Abortion Argument," PQPA 1, no. x (Fall 1971): copyright (C) 197I by Princeton University Press. Michael Tooley, "Abortion and Infanticide," PEPA 2, no. I (Fall I972): copyright (C) 1972 by Princeton University Press. John Finnis, "The Rights and Wrongs of Abortion," PGPA 2, no. 2 (Winter 1973); Judith Jarvis Thomson, "Rights and Deaths," PEPA 2, no. 2 (Winter 1973 ): copyright (C) 1973 by Princeton University Press. Michael Tooley, "A Postscript": copyright (C) 1974 by Princeton University Press.

First Princeton Paperback Printing, 1974 First Hardcover Printing, 1974

Princeton University Press books are printed on acid-free paper and meet the guidelines for permanence and durability of the Committee on Production Guidelines for Book Longevity of the Council on Library Resources

Printed in the United States of America 